\title{
Protoplast Isolation, Fusion, Culture and Transformation in the Woody Plant Jasminum spp.
}

\author{
Mohamed A. A. Ahmed ${ }^{1,2}{ }^{\text {, Miao Miao }}{ }^{1}$, Emmanouil D. Pratsinakis ${ }^{3}{ }^{\oplus}$, Hongliang Zhang ${ }^{1}$, Wei Wang ${ }^{1}$,

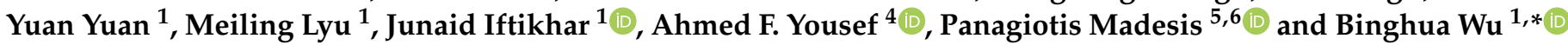 \\ 1 College of Horticulture and the Fujian Provincial Key Laboratory of Plant Functional Biology, \\ Fujian Agriculture and Forestry University, Fuzhou 350002, China; \\ mohamed_marie2009@yahoo.com (M.A.A.A.); 2190514007@fafu.edu.cn (M.M.); \\ 2160371003@fafu.edu.cn (H.Z.); L813061@fafu.edu.cn (W.W.); yuanyuan@fafu.edu.cn (Y.Y.); \\ mllyu@fafu.edu.cn (M.L.); junaidiftikhar@outlook.com (J.I.) \\ 2 Plant Production Department (Horticulture-Medicinal and Aromatic Plants), \\ Faculty of Agriculture (Saba Basha), Alexandria University, Alexandria 21531, Egypt \\ 3 Laboratory of Agronomy, School of Agriculture, Faculty of Agriculture, Forestry and Natural Environment, \\ Aristotle University of Thessaloniki, GR-54124 Thessaloniki, Greece; epratsina@agro.auth.gr \\ 4 Department of Horticulture, College of Agriculture, University of Al-Azhar (Branch Assiut), \\ Assiut 71524, Egypt; ahmedfathy201161@yahoo.com \\ 5 Laboratory of Molecular Biology of Plants, School of Agricultural Sciences, University of Thessaly, \\ GR-38446 Thessaly, Greece; pmadesis@certh.gr \\ 6 Institute of Applied Biosciences, Centre for Research and Technology, Thermi, GR-57001 Thessaloniki, Greece \\ * Correspondence: binghua.wu@fafu.edu.cn; Tel.: +86-591-8637909
}

check for updates

Citation: Ahmed, M.A.A.; Miao, M.; Pratsinakis, E.D.; Zhang, H.; Wang, W.; Yuan, Y.; Lyu, M.; Iftikhar, J.; Yousef, A.F.; Madesis, P.; et al. Protoplast Isolation, Fusion, Culture and Transformation in the Woody Plant Jasminum spp. Agriculture 2021, 11, 699. https:// doi.org/10.3390/agriculture11080699

Academic Editor: Rodomiro Ortiz

Received: 22 June 2021

Accepted: 23 July 2021

Published: 26 July 2021

Publisher's Note: MDPI stays neutral with regard to jurisdictional claims in published maps and institutional affiliations.

Copyright: (c) 2021 by the authors Licensee MDPI, Basel, Switzerland. This article is an open access article distributed under the terms and conditions of the Creative Commons Attribution (CC BY) license (https:// creativecommons.org/licenses/by/ $4.0 /)$.
Abstract: Plant protoplasts are significant for plant cell culture, somatic cell fusion, genetics, and breeding studies. In addition, in vitro plant regeneration has great importance for developmental biology, manifesting potential applications in agriculture and biotechnology. In this regard, we present a well-established protocol regarding protoplast isolation, cell culture and protoplast fusion of Jasminum spp. In particular, different tissues of Jasminum samab L. and Jasminum mesnyi were employed for protoplast isolation, and stem explants provided a high callus induction rate in a short period of time. The best source for protoplast isolation was calli tissues. The optimized isolation protocol consisted of digesting callus in an enzyme solution containing $0.4 \mathrm{M}$ mannitol, $0.2 \mathrm{M}$ MES, $1 \mathrm{M} \mathrm{CaCl}_{2}, 0.2 \mathrm{M} \mathrm{KCL}$ and $1 \mathrm{M} \mathrm{NaH}_{2} \mathrm{PO}_{4}, 1.5 \%$ Cellulases onozuka R-10, 0.4\% Macerozyme R-10 and $0.8 \%$ Pectinase for $4 \mathrm{~h}$ at $26^{\circ} \mathrm{C}$ in the dark, providing a yield of $23.8 \times 10^{6}$ Protoplast $/ \mathrm{gFW}$ with $88 \%$ viability. Protoplasts were cultured both in liquid and agarose medium under optimum conditions, leading to microcalli formation after eight weeks. A 5\% protoplast-fusion rate can be achieved when cultured in $40 \%(w / v)$ PEG-MW6000 supplemented with $0.1 \mathrm{M} \mathrm{CaCl}_{2}, 0.1 \mathrm{M}$ sorbitol and $1 \mathrm{M}$ Tris for 20 min. Furthermore, we developed an efficient PEG-mediated transformation protocol for jasmine protoplasts. The best results regarding protoplast transformation were obtained when the protoplast concentration was $4 \times 10^{5}$ cells $/ \mathrm{mL}$ and the exogenous plasmid DNA added had a concentration of $10 \mu \mathrm{g}$ DNA/100 $\mu \mathrm{L}$ protoplast solution, followed by the application of 40\% PEG-4000 for $10 \mathrm{~min}$.

Keywords: protoplast isolation; Jasminum mesnyi; callus induction; protoplast culture; woody plants; PEG

\section{Introduction}

Jasminum sambac (L.) Ait., an evergreen shrub, is widely cultivated as an ornamental plant in the southern and eastern parts of India. Its flowers provide important raw materials for scented tea and essential oils. Despite the great economic, medicinal, and ornamental value of J. sambac, the major problem encountered in its cultivation is the lack of intraspecies genetic variation [1]. Jasmine is considered a recalcitrant species regarding tissue culture and regeneration [2]. Therefore, overcoming difficulties in J. sambac regeneration could be a critical step for future studies and for genetic diversity through callus formation [2]. 
Plant tissue culture is regarded as a suitable technology for crop improvement with high efficiency in terms of somaclonal as well as gametoclonal variants development. Micropropagation could be used to cultivate materials of higher quality. It can also be used for the introduction of genetic diversity and selection of beneficial variants of high yield with improved tolerance to biotic or abiotic stresses [3,4]. Protocols on tissue culture for most crop species are already available, but for several species, such as woody plant species, such protocols still need to be optimized [4].

Microculture has been frequently used for ornamental shrubs as well as trees; nevertheless, using such a system on woody perennial species is usually more complicated, compared to the systems employed in herbaceous crops [5]. Successful protocol for regeneration of plantlet from explants in woody plant species is often species or even cultivardependent [5]. Calli can be induced from different plant organs, varying from leaf, seed, stem, and inflorescence. Calli can also serve as the source for cell suspensions. In vitro organogenesis refers to the process in which isolated plant tissues or cells re-differentiate and form stems, leaves, roots, or even flower buds under specific culture conditions [6]. The protocol for plant regeneration for in vitro organogenesis of woody plants is basically similar to that of herbaceous plants. However, it is difficult to establish an efficient regeneration system for woody plant species and achieve significant organogenesis; thus, relatively few examples have been reported [7].

Plant breeding and improvement of plant varieties for desirable traits through protoplast and regeneration technology is becoming particularly significant due to somatic hybridization and the possible transformation of protoplast, especially for recalcitrant species [8]. However, a successful protocol for protoplast isolation, cultivation, and regeneration is a key step towards plant genetic manipulation and a combined breeding program [9].

Protoplast fusion is a suitable method to transfer genes between varieties or species to develop new varieties with desirable traits, like quality and yield [10]. Such technology includes fusion between two genetically distinct protoplasts derived from diverse somatic cells to obtain parasexual protoplast hybrids [10,11]. However, to implement protoplast fusion, an efficiently established tissue culture system is necessary, including isolation of protoplast and regeneration [12]. Plant protoplasts are a cell-based experimental model, as such they can be employed to incorporate macromolecules, e.g., DNA, RNA, and proteins, using various approaches, including electroporation, PEG-assisted transformation, and microinjection $[13,14]$.

Transient expression assays using protoplast are also highly suitable for quick and high-throughput studies for protein activity, protein-protein interactions, subcellular protein localization, and gene expression [15]. In order to study and use the plant-genetic capability of any species, an efficient tissue culture, regeneration and transformation system is regarded as the main requirement. At this stage, the research on the transient transformation of plant cells mainly focuses on model plants; thus, there are relatively few studies on floral plants. Furthermore, there is no reference on Jasminum spp. protoplast culture, and thus, PEG-mediated transformation techniques for protoplast isolation are poorly studied. In this study, the effects of cytokinin alone or in combination with auxin and the callus induction conditions, such as the medium selection for inducing callus or regenerating stems or roots from leaf or stem segments of Jasminum sambac and Jasminum mesnyi were investigated. The objective of the present study was to describe an implemented, reliable, and suitable protocol for protoplast isolation from different Jasminum tissues, their cell culture, and their protoplast fusion. PEG-mediated DNA transformation of protoplasts in Jasminum protoplasts is also described as an alternative transformation technique of J. sambac (L.) or other species from the same genus. 


\section{Materials and Methods}

\subsection{Materials Sources and Culture Conditions}

Plants of J. sambac and J. mesnyi were cutting-propagated and maintained in pots (30 $\mathrm{cm}$ diameter $\times 30 \mathrm{~cm}$ height) in the nursery of the Horticulture Garden at the University before being used in the experiment. Two months before sampling, the three-year-old plants were moved to a growth chamber setting a temperature of $24 / 28^{\circ} \mathrm{C}$ and a $14 \mathrm{~h} / 10 \mathrm{~h}$ (light/dark) photoperiod with a 65\% humidity. In total, 30-45 plants from 15 pots were used as sampling sources for each species. The leaves, flowers, stems and callus tissue were investigated for protoplast isolation.

For callus induction, young shoots were used. The young shoots of jasmine plants with 4 tender leaves at the top were detached, and explants were washed with water and detergent for $30 \mathrm{~min}$ to remove dirt. They were then rinsed under running tap water for 1 $h$ and surface sterilized, followed by moving the segments into a laminar-air flow cabinet. The young shoots were then soaked in a tissue culture bottle with $75 \%$ ethanol for $30 \mathrm{~s}$ and were rinsed 3 times with sterile distilled water, followed by subsequent addition of $20 \%$ of chlorine 84 containing 2 drops of Tween 20 for $15-18 \mathrm{~min}$. The shoots were washed for 3-5 times with sterile distilled water and then submerged in sterile distilled water for further use. The shoots were cut into segments $(\sim 0.5-\mathrm{cm}-\mathrm{long})$ and utilized as explants. Such stem segments and leaf explants of these plants were selected and served as donors for obtaining in vitro explants. The explants were inoculated into an induction medium MS [16] or a mineral salt medium of Woody Plant Medium (WPM) [17], which is the most extensively utilized for the microculture regarding woody crops growth. Each medium was supplemented with 6-BA and NAA (WPM or/and MS + $2 \mathrm{mg} / \mathrm{L}$ 6-BA + $0.2 \mathrm{mg} / \mathrm{L} \mathrm{NAA}+$ $30 \mathrm{~g} / \mathrm{L}$ sucrose $+7.5 \mathrm{~g} / \mathrm{L}$ agar). The culture jars were placed in a tissue culture room and kept at a temperature of 23 to $27^{\circ} \mathrm{C}$, a light intensity of 1200 to 2000 lux (LED light source), and a photoperiod of $12 \mathrm{~h} / \mathrm{d}$. Each medium was replicated three times (20 jars/replicate). The produced calli, were selected and inoculated into a fresh medium for subculture every 2 weeks.

\subsection{Factors Affecting the Yield and Viability of the Isolated Protoplasts}

The conventional method (one-factor-at-a-time) [18] was applied to optimize the protoplast isolation from different tissues of $J$. sambac. The effects of different protoplast enzymes and buffer solutions on the protoplast number and their viability were investigated $[19,20]$. Furthermore, the influence of incubation time on the yield and protoplasts viability was also analyzed for determining the required optimal time towards a complete release of protoplasts. Thus, the leaf tissues were incubated for 4, 5, 6, 8 and $10 \mathrm{~h}$ in the protoplast isolation buffer. The flowers were incubated for 4, 6, 8, and $10 \mathrm{~h}$. The callus slices were incubated for 4,5 and $6 \mathrm{~h}$, and the stem cuttings were incubated for 5, 6 and $8 \mathrm{~h}$. The effect of enzyme solution volume was also tested. As soon as a leaf was cut into strips, then the strips were transferred into the prepared enzyme solution $(2.5,5$ and $10 \mathrm{~mL})$ and the strips were completely dipped into the solution using a pair of sterilized flat-tip forceps. Various enzyme solution volume-ratios were tested as specified in the Results Section.

\subsection{Isolation, Purification and Determination of the Protoplasts Yield and Viability}

The separation of young, expanded leaves, flowers, and stems from the new shoots of plants growing in the greenhouse was applied for protoplast isolation. Surface sterilization of leaves, flowers and stems was performed using $70 \%$ ethanol for $60 \mathrm{~s}$. Then, the explants were immersed into a $0.4-0.5 \%$ sodium hypochlorite solution for $30 \mathrm{~min}$ and treated with chlorine 84 and Tween 20 for $20 \mathrm{~min}$. All the sterilization steps were performed inside a laminar airflow hood. After $30 \mathrm{~min}$, the sterilant was poured off, and the tissues were aseptically washed with sterilized double-distilled water (3-4 times) to remove any hypochlorite traces. The tissues (approximately $1 \mathrm{~g}$ ) were immediately cut into strips $(0.5 \mathrm{~mm})$ with a fresh razor blade and placed on a $60 \times 15 \mathrm{~mm}$ Petri dish, and then a buffer solution was added (Table 1), and the vacuum infiltration was performed for $30 \mathrm{~min}$ in 
the dark. After that, the digestion solution was passed through $0.45 \mu \mathrm{m}$ membrane filters and put in a water bath at $55^{\circ} \mathrm{C}$ for $10 \mathrm{~min}$ in order to enhance enzyme solubility [21], and vacuum infiltration was then performed again for $30 \mathrm{~min}$. To isolate the protoplast from the callus, a 4-6-week-old callus was cut into slices $(0.3-0.5 \mathrm{~mm})$ using a fresh razor blade. Such obtained callus slices were directly placed into the buffer solution, vacuum filtration was then performed for $30 \mathrm{~min}$, and the enzyme digestion mixture was added (Table 1). The dishes containing leaf, flower, stem, callus tissues and enzymes were sealed with Parafilm ${ }^{\mathrm{TM}}$ and incubated at 26 to $30^{\circ} \mathrm{C}$ in the dark, followed by gentle shaking for one hour at $50 \mathrm{rpm}$ in low light or darkness. For purification, digested suspension of leaf, flower, stem, and callus were filtered through a $150 \mu \mathrm{m}$ sterile nylon mesh to remove coarse and undigested cells. The protoplast suspensions were transferred into $15 \mathrm{~mL}$ centrifuge tubes and centrifuged for five minutes at $200 \times g\left(4^{\circ} \mathrm{C}\right)$. The supernatants were then removed, while the pellets were resuspended gently in the W5 solution (Table 1) to the centrifuge tubes. The pellets were purified by floating in $2 \mathrm{~mL}$ of $\mathrm{K} 3$ solution ( $21 \%$ $(w / v)$ sucrose). The protoplast was placed in a head tube that was centrifuged for three minutes at $100 \times g$. The middle layer protoplasts were collected (the purified protoplasts were placed in the middle between the two solutions, while the debris were pelleted to the bottom of the K 3 solution), and the W5 solution was then added very carefully. The protoplasts were then centrifuged at $200 \times g$ for five minutes, and the supernatant was placed in a $1.5 \mathrm{~mL}$ W5 solution, and the centrifuge tube was then placed on ice.

Table 1. Solution recipes for protoplast isolation and transformation.

\begin{tabular}{|c|c|c|c|}
\hline Solution Name & Solution Composition & Storage & Function \\
\hline Buffer solution & 0.4 M Mannitol, $0.2 \mathrm{M}$ MES, $1 \mathrm{M}$ & Freshly prepared & Digestion of cell wall material \\
\hline Enzyme solution & $\begin{array}{c}1.5 \% \text { Cellulases Onozuka R10, } \\
\text { 1.5\% Cellulases Onozuka RS, } \\
0.4 \% \text { Macerozyme R-10, } \\
0.8 \% \text { Pectinase }\end{array}$ & Freshly prepared & Digestion of cell wall material \\
\hline W5 & $\begin{array}{c}2 \mathrm{mM} \text { MES, } 154 \mathrm{mM} \mathrm{NaCl}, 125 \mathrm{mM} \\
\mathrm{CaCl} 2 \text { and } 5 \mathrm{mM} \mathrm{KCl},(\mathrm{pH} 5.7)\end{array}$ & $4^{\circ} \mathrm{C}$ & Release and washing protoplasts \\
\hline W1 & $\begin{array}{l}\text { 0.8 M Mannitol, } 10 \text { mM KCL, } \\
20 \mathrm{mM} \text { MES (pH 5.7), ddH } \mathrm{d}_{2} \mathrm{O}\end{array}$ & Freshly prepared & $\begin{array}{l}\text { Re-suspend protoplast } \\
\text { after transfection }\end{array}$ \\
\hline $\mathrm{MMg}$ & $\begin{array}{l}\text { 0.8 M Mannitol, } 10 \mathrm{mM} \mathrm{CaCl}_{2} \\
20 \mathrm{mM} \text { MES (pH 5.7), } \mathrm{ddH}_{2} \mathrm{O}\end{array}$ & Freshly prepared & $\begin{array}{l}\text { Res-uspend the protoplast for } \\
\text { counting and transfection }\end{array}$ \\
\hline PEG & $\begin{array}{c}40 \%(w / v) \text { PEG } 4000,0.8 \mathrm{M} \text { Mannitol } \\
\text { and } 0.1 \mathrm{M} \mathrm{Ca}\left(\mathrm{NO}_{3}\right)_{2}\end{array}$ & Freshly prepared & $\begin{array}{l}\text { Transform plasmids ( } 10 \mathrm{ug} \text { is used in } \\
\text { this study) into protoplasts }\end{array}$ \\
\hline
\end{tabular}

The protoplast yield was estimated by cell counting using a haemocytometer (ModifiedFuchs Rosenthal rulings, model BS 74B; Weber Scientific International Ltd., Teddington, UK), and observed under a fluorescence microscope (Axio image A2-AxioCam HRc). The purified protoplasts viability test was evaluated using fluorescein diacetate $(0.01 \%(w / v)$ FDA). The stained protoplasts were considered as only vital protoplasts, while the dead ones remained unstained [22,23]. A volume of stained protoplasts $(13 \mu \mathrm{L})$ was loaded at a side of haemocytometer, followed by counting the number of viable protoplasts. This number per gram of the fresh weight was then calculated (Protoplast yield/gFW).

\subsection{Protoplast Staining and Image Acquisition for Cellulose Fibrils}

In the first week of culture, cell wall regeneration was monitored by staining the protoplasts using $0.001 \%(w / v)$ of calcofluor white (Fluorescent Brightener 28) solution supplied by Sigma-Aldrich. 


\subsection{PEG-Induced Protoplast Fusion}

Protoplast fusion between J. sambac and J. mesnyi was performed using polyethylene glycol (PEG). Four different parameters, including molecular weight of PEG, concentrations of PEG, fusion solution compositions, and fusion time, were assessed. Specifically, different molecular weights (MW) and concentrations of PEG, PEG-6000 and PEG-4000 were used as a fusion agent (Fusogen) at 3 different concentrations (30, 40 and 50\%). Six different fusion solutions and three different treatment durations were investigated in this study. Different combinations of six fusion solutions were used as follows: the first fusion solution comprises of 30\% (w/v) PEG MW 4000 supplemented with $4 \%(w / v)$ sucrose and $10 \mathrm{mM}$ $\mathrm{CaCl}_{2} \cdot 2 \mathrm{H}_{2} \mathrm{O}$, the second fusion solution comprises $40 \%(w / v)$ PEG MW 4000 supplemented with $0.1 \mathrm{M} \mathrm{CaCl}_{2}, 0.1 \mathrm{M}$ sorbitol and $1 \mathrm{M}$ Tris, the third fusion solution comprises $50 \%(w / v)$ PEG MW 4000 supplemented with $50 \mathrm{mM} \mathrm{CaCl} \cdot 2 \mathrm{H}_{2} \mathrm{O}$ and $10 \mathrm{mM}$ mannitol, the fourth fusion solution comprises 30\% (w/v) PEG MW 6000 supplemented with $4 \%(w / v)$ sucrose and $10 \mathrm{mM} \mathrm{CaCl} 2 \cdot 2 \mathrm{H}_{2} \mathrm{O}$, the fifth fusion solution comprises $40 \%(w / v)$ PEG MW 6000 supplemented with $0.1 \mathrm{M} \mathrm{CaCl}_{2}, 0.1 \mathrm{M}$ sorbitol and $1 \mathrm{M}$ Tris, and finally, the sixth fusion solution comprises $50 \%(w / v)$ PEG MW 6000 supplemented with $50 \mathrm{mM} \mathrm{CaCl}_{2} \cdot 2 \mathrm{H}_{2} \mathrm{O}$ and $10 \mathrm{mM}$ mannitol. Equal volumes of purified callus protoplasts of J. sambac and J. mesnyi were mixed at a ratio of $1: 1(v / v)$ density, and $100 \mu \mathrm{L}$ of the mixture was transferred into each micro-centrifuge tube and mixed with the fusion solution of 30,40 and $50 \%(w / v)$ of PEG (MW 4000 and MW 6000) and centrifuged at $750 \mathrm{rpm}$ at $10^{\circ} \mathrm{C}$ and incubated at 3 different time intervals (15, 20 and $25 \mathrm{~min}$ ) [23-29]. The occurrence of binary fusion (fusion of only two protoplasts) was recorded under an inverted microscope, and the percentages of binary fusion were calculated using the following formula:

Percentages of binary fusion $(\%)=$ Number of fusions between only two protoplasts $/$ Total number of

$$
\text { protoplasts } \times 100
$$

\subsection{Transient Transformation of Protoplasts}

Regarding the transient transformation of protoplasts, we used two plasmids (atsip2mCherry and JsSWEET5-GFP). The constructed vectors were electro-transformed into E. coli T1 cells. The extraction of plasmids was performed using the Maxi prep kit (TIANpure plasmid kit II, TianGen Co., Beijing, China) and yielded 744.2 ng/ $\mu \mathrm{L}$ of JsSWEET5-GFP plasmid DNA and $744 \mathrm{ng} / \mu \mathrm{L}$ of atsip2-mCherry plasmid DNA. The PEG-mediated transformation was performed using Jasminum callus protoplasts according to the method developed by Yoo et al. [21] for Arabidopsis, with some modifications. Briefly, plasmid DNA $(10 \mu \mathrm{g})$ was mixed with freshly isolated protoplasts $(100 \mu \mathrm{L})$ at room temperature (RT), and freshly prepared PEG $(110 \mu \mathrm{L})$ solution was added. Tubes were gently inverted several times (upside down) for two minutes to mix the contents, and then they were incubated for $8 \mathrm{~min}$ at RT in the dark to allow for plasmid transformation to occur. Then, the W5 solution of five volumes more than PEG solution (440-550 $\mu \mathrm{L})$ was slowly added, gently mixed by inverting the tubes. After centrifugation at $700 \times g$ for $5 \mathrm{~min}$, the pellet was then resuspended gently in $100 \mu \mathrm{L}$ of the $\mathrm{W} 1$ solution (Table 1). Finally, the protoplast suspension was transferred in $2 \mathrm{~mL}$ tubes, followed by room-temperature incubation for $12 \mathrm{~h}$ in the dark.

After $12 \mathrm{~h}$ of incubation, $13 \mu \mathrm{L}$ of the transformed protoplasts were observed under a confocal laser scanning microscope (Leica TCS SP8X) for GFP, mCherry, merged and chloroplast auto-fluorescence, using the excitation wavelengths set of 488-507 nm for GFP, 597-648 $\mathrm{nm}$ for mCherry and 659-749 $\mathrm{nm}$ for chloroplast auto-fluorescence. 


\subsection{Protoplast Culture}

The initial culture of protoplasts was achieved at a density of $1.0 \times 10^{5}$ cells per mL in a (i) liquid medium and (ii) agarose culture. For the liquid culture, the protoplasts were suspended in $50 \mathrm{~mm}$ Petri dishes having $4 \mathrm{~mL}$ of a sterilized liquid medium that included full MS macro- and micronutrients except for $\mathrm{NH}_{4} \mathrm{NO}_{3}, 30 \mathrm{~g} / \mathrm{L}$ glucose, $3.0 \mathrm{~g} / \mathrm{L}$ glutamine, $9 \%$ mannitol $(0.5 \mathrm{M})$, and appropriate plant growth regulators (PGRs), namely: $\alpha$ - naphthylacetic acetic acid (NAA) in combination with 6-BA and adjusted at $\mathrm{pH}$ of 5.8. The incubation of culture was performed between 21 and $26{ }^{\circ} \mathrm{C}$ in the dark, and the addition of fresh medium $(2 \mathrm{~mL})$ every 10 days was carried out to the culture medium. For preventing cultures from browning, refreshment of MS liquid medium was accomplished when half of the volume $(2 \mathrm{~mL})$ of the current medium was replaced by an identical volume of fresh medium every seven days. For the culture, the protoplasts were cultured on full MS macro- and micronutrients except for $\mathrm{NH}_{4} \mathrm{NO}_{3}, 30 \mathrm{~g} / \mathrm{L}$ glucose, $3.0 \mathrm{~g} / \mathrm{L}$ glutamine, $9 \%$ mannitol $(0.5 \mathrm{M})$ was used in Petri dishes cultured with $1.5 \mathrm{~mL}$ of liquid medium, and half of the liquid medium was refreshed every seven days with fresh medium. The successful prevention of contaminations was achieved by adding Clorox ( $5.5 \%$ sodium hypochlorite) into WPM and MS media at a $4 \mathrm{~mL} / 1 \mathrm{~L}$ ratio.

\subsection{Statistical Data Analysis}

Data resulting from all experiments were first presented through descriptive statistics. All experiments were analyzed according to the completely randomized design (CRD) with the analysis of variance (ANOVA) method, except one that was analyzed with $t$ test. Separation of means was accomplished with the least significant difference test at significance level $a=0.05(p \leq 0.05)$. More specifically:

The experiment "the effect of plant growth regulators on callus induction from stem segment and shooting rate of J. mesnyi" has 29 treatments and each treatment has three replicates.

The experiment "protoplast yield and viability of isolated protoplast from leaves, flowers, stems and callus of J. sambac L. using different enzyme solutions" was designed as a split plot (main plot was the enzyme and buffer combination, with 2 levels, and the sub plot was the incubation time with 5 levels) and each treatment was replicated three times.

The experiment "effects of different fusion solution and fusion time on protoplast fusion frequency (\%) between J. sambac. L and J. mesnyi" was designed as a split plot (main plot was the fusion solution with 6 levels, and the sub plot was the fusion time, with 3 levels) and each treatment was replicated three times.

The experiment "effect of different molecular weight of PEG on protoplast fusion between J. sambac. L. and J. mesnyi" was analyzed using a $t$-test.

All statistical analyses were performed with the $\operatorname{SPSS}^{\circledR}$ v.23.0 statistical software (SPSS Inc., Chicago, IL, USA).

\section{Results}

\subsection{Establishment of J. sambac and J. mesnyi Callus Cultures for Protoplast Isolation}

We established an efficient in vitro culture system for protoplast isolation from calli, using different plant explants from two jasmine species, Jasminum sambac and Jasminum mesnyi. There were significant differences in the effect of the culture media type on the callus induction between stem segments and leaf explants when woody plant medium (WPM) was used instead of Murashinge and Skoog (MS) medium (Table S1). Calli could be induced from stem explants with inconstant efficacy, responding to a large range of combinations, including 6-benzylaminopurine $(2 \mathrm{mg} / \mathrm{L}$ 6-BA) and 1-naphthaleneacetic acid $(0.2 \mathrm{mg} / \mathrm{L}$ NAA) on modified WPM basal medium. The most effective medium for callus induction from stem segments was WPM or/and MS supplied with $2 \mathrm{mg} / \mathrm{L}$ 6-BA and $0.2 \mathrm{mg} / \mathrm{L}$ NAA, after 30 days of culture. After 10 days culture, leaf segments began to rewind, and after 21 days, the explants became swollen and a thin layer of calli in pale 
white color were developed. A small pale green dense callus mass was produced after 28 days from $\mathrm{J}$. sambac leaf explants, the callus grew very slowly and eventually became brown. The callus induction, on the other hand, was much higher for J. mesnyi leaf explants. In contrast, callus could be easily induced from the stem explants than from the leaf ones (Figure 1a,b).
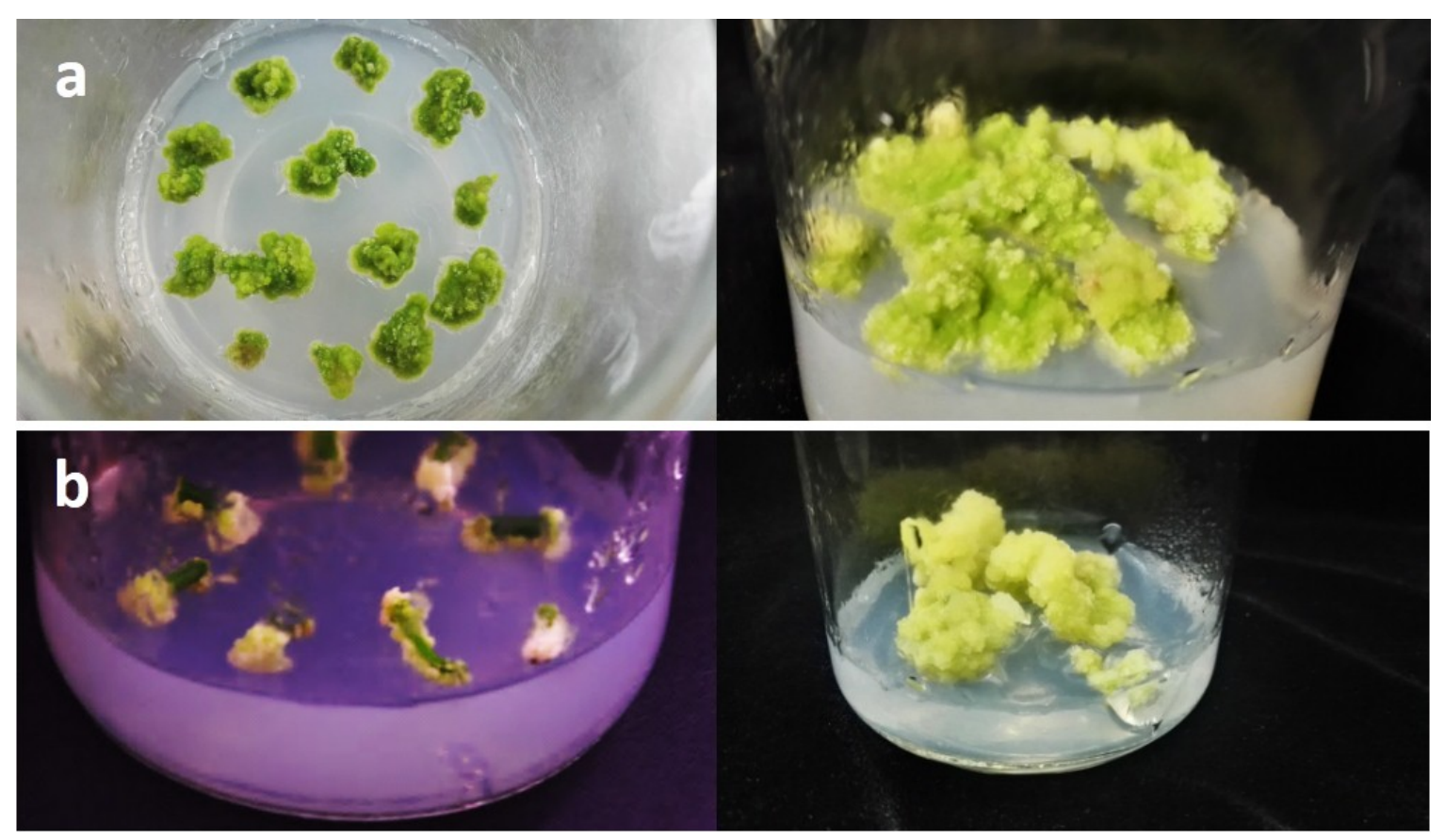

Figure 1. Massive production of callus from stem explants of (a) J. sambac and (b) J. mesnyi on WPM medium supplemented with $0.2 \mathrm{mg} / \mathrm{L} \mathrm{NAA}+2 \mathrm{mg} / \mathrm{L} 6-\mathrm{BA}(\mathbf{a}, \mathbf{b})$ after 14 days in culture.

The ratio of auxin and cytokinin had a profound impact on callus induction from stem explants, the combinations of 0 auxin-1.5 mg/L 6-BA (Treatment 3), $0.5 \mathrm{mg} / \mathrm{L} \mathrm{NAA} \mathrm{+}$ $2 \mathrm{mg} / \mathrm{L}$ 6-BA (Treatment 6) and 0 auxin $+1 \mathrm{mg} / \mathrm{L} \mathrm{KT}$ (Treatment 28) gave after 30 days of culture the highest callus induction percentage. (Table 2 and Figure S1).

Treatment 16, (15.75 mg/L BAP + $5.25 \mathrm{mg} / \mathrm{L}$ NAA) and Treatment 25 (2.00 mg/L BAP $+0.60 \mathrm{mg} / \mathrm{L}$ NAA) produced similar results. However, an occasional shoot regeneration with an induction rate of less than $1 \%$ through the extended culture stage of 3-4 months' post explanting was recorded (Table 2). 
Table 2. Effect of plant growth regulators on callus induction from stem segment and shooting rate of J. mesnyi.

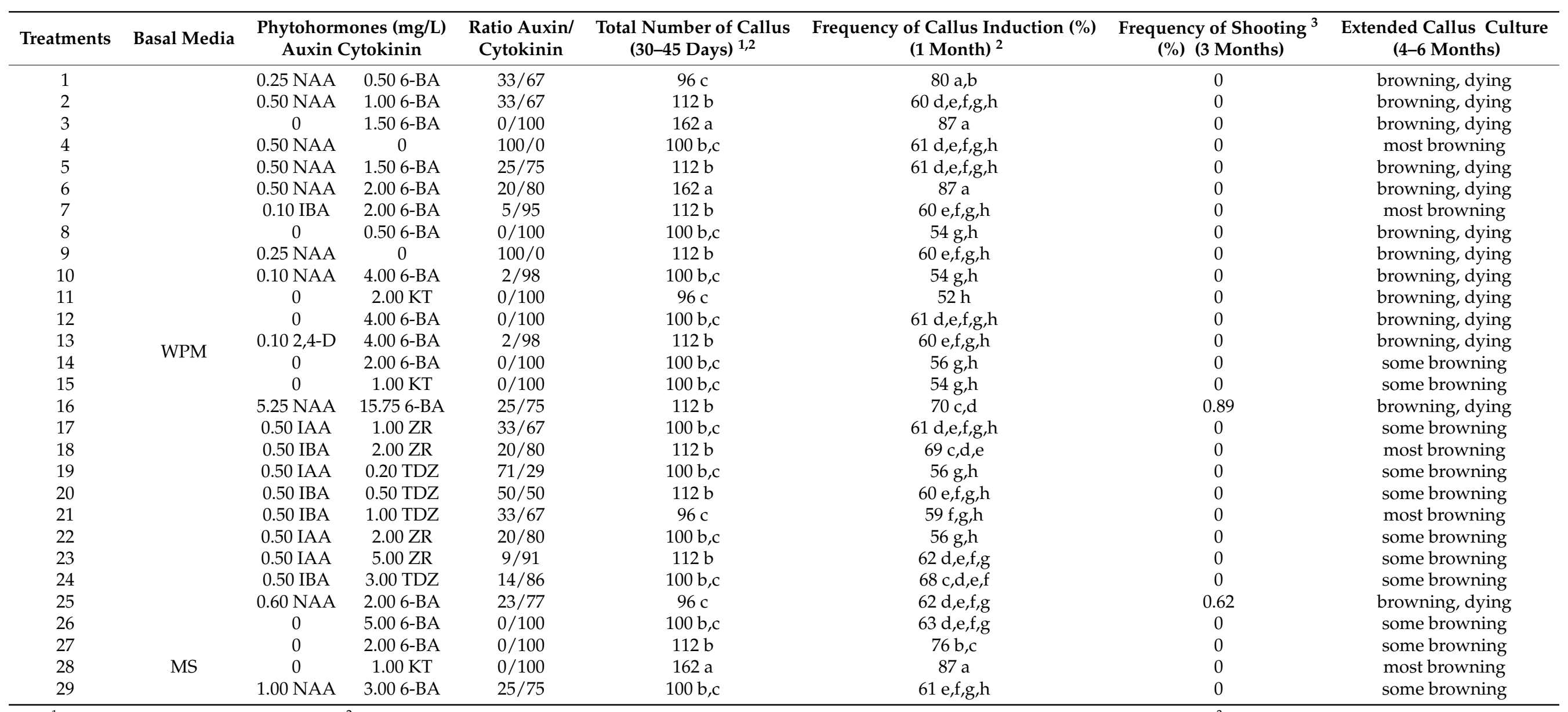

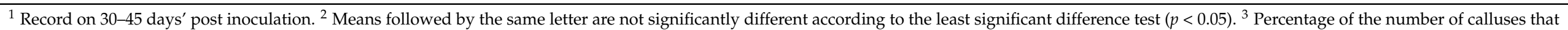
continued to developed shoot after 3 months. 
3.2. Optimization of Factors Affecting Protoplast Isolation and Transient Transformation System of Jasmine Protoplasts

Preliminary attempts to isolate protoplasts from jasmine leaves and stems were made. However, most of the obtained protoplasts were just cell fragments of abnormal shapes. Moreover, we achieved good production and viability of protoplasts using jasmine petals and callus tissues in the same enzymolysis solution, as in stems (Figure 2).

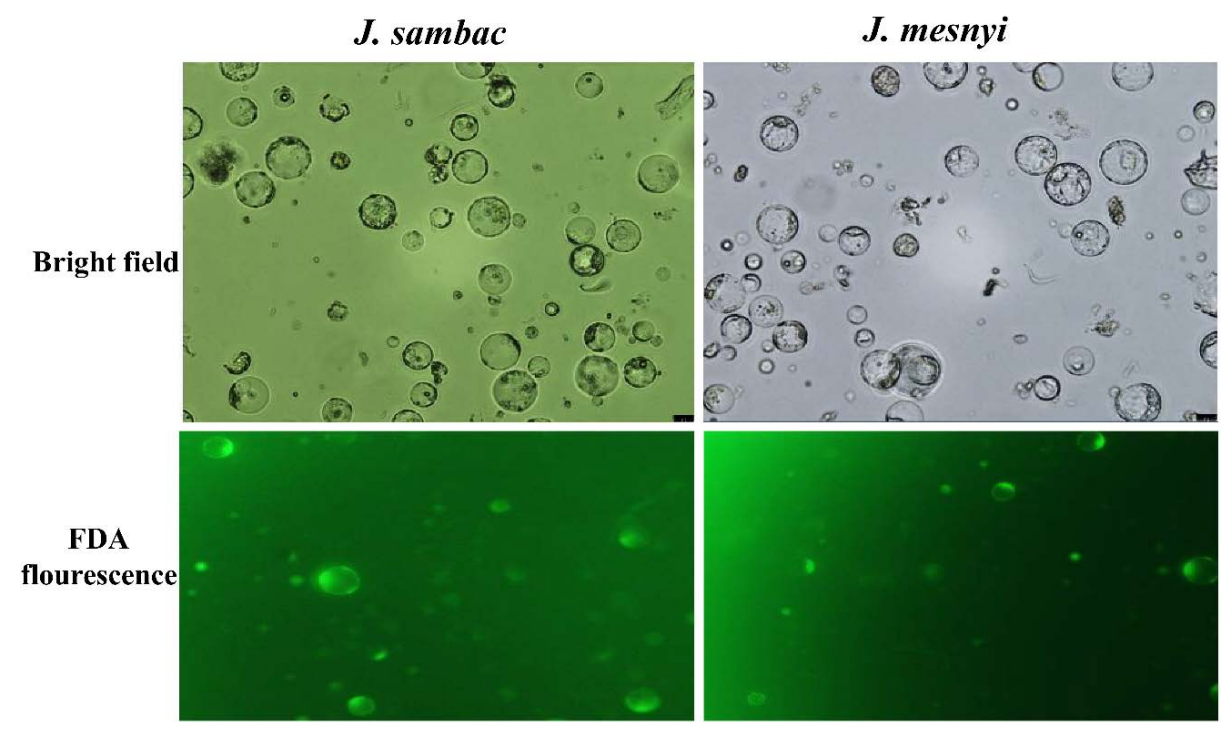

Figure 2. Protoplast isolation from callus tissue of J. sambac L. and J. mesnyi. Freshly isolated protoplasts from callus tissues in bright field and fluorescence channel under a confocal microscope. Bar $=25 \mu \mathrm{m}$.

ANOVA showed statistically significant differences for all treatments for the combination "(Enzyme and Buffer combinations) $\times$ Time" apart from yield derived from flowers (Table 3). Solution 1 (Cellulases Onozuka R10 (1.5\%), Macerozyme R-10 (0.4\%), Cellulases Onozuka RS (1.5\%) and Pectinase $(0.8 \%)$ ) produced $3.3 \times 10^{6}$ protoplast $/ \mathrm{gFW}$ (fresh weight) from leaves, flowers, and stems, and $12.1 \times 10^{6}$ protoplast/gFW from callus with protoplasts viability of $84.0 \%, 70.6 \%, 72.3 \%$ and $81.5 \%$, respectively. Solution 2 (Cellulases Onozuka R10 (1.5\%), Macerozyme R-10 (0.4\%) and Pectinase $(0.8 \%))$ produced the highest yield and viability of protoplasts with $5.6 \times 10^{6}$ protoplast/gFW from leaves, $3.9 \times 10^{6}$ protoplast/gFW from flowers, $3.1 \times 10^{6}$ protoplast $/ \mathrm{gFW}$ from stems and $23.8 \times 10^{6}$ protoplast/gFW from callus tissue produced representing $89.6 \%, 83.0 \%, 72.5 \%$ and $88.0 \%$, respectively. In addition, the highest yield and viability were obtained from enzyme solutions and buffer solution 2 supplemented with $0.4 \mathrm{M}$ mannitol, $0.2 \mathrm{M} \mathrm{MES,} 1 \mathrm{M} \mathrm{CaCl}_{2}$, $0.2 \mathrm{M} \mathrm{KCL}$ and $1 \mathrm{M} \mathrm{NaH}_{2} \mathrm{PO}_{4}$ (Table 3).

The yield of protoplasts was $7.3 \times 10^{6}$ protoplasts $/ \mathrm{gFW}$ after a six-hour incubation into enzyme solutions and buffer solution 2, whereas the protoplasts viability was 55.7\%. The most favorable digestion time for a high viable protoplast yield from leaves was eight hours. The six-hour incubation time was insufficient for digestion of leaf tissues (Figure 3). The optimum duration time of digestion for petals was $10 \mathrm{~h}$ (Figure 3), which produced up to $8.9 \times 10^{6}$ protoplasts per gram of fresh weight with viability of $81.5 \%$. It was also noted that petals should be sampled better at 19:00 of the opening day, because the flowers may undergo senescence during the next day, making it difficult to obtain the optimized yield (Table 3). Furthermore, the protoplast number and viability from stems are shown in Figure 3. Use of five, six, or eight-hour incubation time was sufficient for the digestion of stem tissue. The highest protoplast yield and quality produced from the stems tissue were obtained after a six-hour incubation period. Meanwhile, the highest protoplasts yield and viability from callus were produced after four hours of incubation (Figure 3 ), which gave $9.4 \times 10^{6}$ protoplast/gFW with viability higher than $88.0 \%$. 
Table 3. Protoplast yield and viability of isolated protoplast from leaves, flowers, stems and callus of J. sambac L. using different enzyme solutions.

\begin{tabular}{|c|c|c|c|c|c|c|c|c|c|}
\hline \multirow{2}{*}{$\begin{array}{c}\text { Enzyme and } \\
\text { Buffer } \\
\text { Combinations }\end{array}$} & \multirow{2}{*}{ Time } & \multicolumn{4}{|c|}{ Yield $\left(\times 10^{6}\right.$ protoplasts/gFW $)$} & \multicolumn{4}{|c|}{ Viability (\%) } \\
\hline & & Leaves & Flowers & Stems & Callus & Leaves & Flowers & Stems & Callus \\
\hline \multirow[t]{6}{*}{ 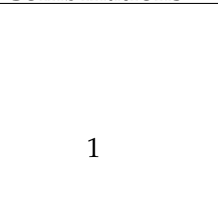 } & 1 & $2.5 \pm 0.3 \mathrm{~b}, \mathrm{c}, \mathrm{d}$ & $2.4 \pm 0.4 \mathrm{a}$ & $0.4 \pm 0.0 \mathrm{e}$ & $1.2 \pm 0.0 \mathrm{e}$ & $63.7 \pm 5.3 \mathrm{~d}$ & $54.4 \pm 1.9 \mathrm{~d}$ & $72.3 \pm 3.1 \mathrm{a}$ & $80.3 \pm 1.9 \mathrm{c}, \mathrm{d}$ \\
\hline & 2 & $3.3 \pm 0.5 \mathrm{~b}$ & $2.8 \pm 0.2 \mathrm{a}$ & $0.2 \pm 0.0 \mathrm{e}$ & $1.6 \pm 0.0 \mathrm{e}$ & $63.2 \pm 3.0 \mathrm{~d}$ & $63.5 \pm 3.6 \mathrm{c}$ & $61.1 \pm 1.1 \mathrm{~b}, \mathrm{c}$ & $78.8 \pm 2.7 \mathrm{c}, \mathrm{d}$ \\
\hline & 3 & $1.4 \pm 0.3 \mathrm{c}, \mathrm{d}, \mathrm{e}$ & $2.8 \pm 0.2 \mathrm{a}$ & $1.4 \pm 0.3 \mathrm{~d}$ & $5.4 \pm 2.0 \mathrm{~d}$ & $84.0 \pm 1.6 \mathrm{a}, \mathrm{b}$ & $70.6 \pm 1.3 \mathrm{~b}$ & $57.5 \pm 1.1 \mathrm{c}$ & $72.8 \pm 2.9 \mathrm{e}$ \\
\hline & 4 & $3.2 \pm 0.5 \mathrm{~b}, \mathrm{c}$ & $3.1 \pm 0.2 \mathrm{a}$ & $3.3 \pm 0.5 \mathrm{a}$ & $12.1 \pm 3.8 b, c$ & $77.7 \pm 2.8 \mathrm{~b}, \mathrm{c}$ & $61.8 \pm 6.2 \mathrm{c}$ & $63.0 \pm 0.8 \mathrm{~b}$ & $81.5 \pm 1.2 \mathrm{~b}, \mathrm{c}$ \\
\hline & 5 & $0.18 \pm 0.0 \mathrm{e}$ & $3.3 \pm 0.1 \mathrm{a}$ & $2.8 \pm 0.1 \mathrm{~b}$ & $1.3 \pm 0.0 \mathrm{e}$ & $46.5 \pm 3.5 \mathrm{e}$ & $61.5 \pm 3.0 \mathrm{c}$ & $64.2 \pm 2.7 \mathrm{~b}$ & $75.7 \pm 1.5 \mathrm{~d}, \mathrm{e}$ \\
\hline & 1 & $5.4 \pm 0.1 \mathrm{a}$ & $0.1 \pm 0.0 \mathrm{a}$ & $2.3 \pm 0.1 \mathrm{~b}$ & $11.3 \pm 0.4 c$ & $89.6 \pm 8.0 \mathrm{a}$ & $61.6 \pm 1.2 \mathrm{c}$ & $72.5 \pm 2.0 \mathrm{a}$ & $88.0 \pm 2.7 \mathrm{a}$ \\
\hline \multirow{4}{*}{2} & 2 & $1.1 \pm 0.0 \mathrm{~d}, \mathrm{e}$ & $3.9 \pm 5.0 \mathrm{a}$ & $2.2 \pm 0.1 \mathrm{c}$ & $14.1 \pm 1.5 \mathrm{~b}$ & $88.1 \pm 4.6 \mathrm{a}$ & $82.2 \pm 1.6 \mathrm{a}$ & $44.6 \pm 3.0 \mathrm{e}$ & $86.6 \pm 5.8 \mathrm{a}, \mathrm{b}$ \\
\hline & 3 & $2.5 \pm 0.3 \mathrm{~b}, \mathrm{c}, \mathrm{d}$ & $2.0 \pm 1.3 \mathrm{a}$ & $0.1 \pm 0.0 \mathrm{e}$ & $23.8 \pm 4.3 \mathrm{a}$ & $78.7 \pm 6.4 \mathrm{~b}, \mathrm{c}$ & $83.0 \pm 2.8 \mathrm{a}$ & $53.3 \pm 1.1 \mathrm{~d}$ & $76.7 \pm 2.0 \mathrm{c}, \mathrm{d}, \mathrm{e}$ \\
\hline & 4 & $1.7 \pm 0.4 \mathrm{~b}, \mathrm{c}, \mathrm{d}, \mathrm{e}$ & $0.2 \pm 0.0 \mathrm{a}$ & $0.2 \pm 0.0 \mathrm{e}$ & $14.5 \pm 3.6 \mathrm{~b}$ & $72.6 \pm 5.6 c$ & $42.4 \pm 2.0 \mathrm{e}$ & $69.2 \pm 2.8 \mathrm{a}$ & $81.5 \pm 4.3 \mathrm{~b}, \mathrm{c}$ \\
\hline & 5 & $5.6 \pm 3.9 \mathrm{a}$ & $0.1 \pm 0.0 \mathrm{a}$ & $3.1 \pm 0.2 \mathrm{a}$ & $12.6 \pm 1.8 \mathrm{~b}, \mathrm{c}$ & $49.2 \pm 3.0 \mathrm{e}$ & $53.6 \pm 2.7 \mathrm{~d}$ & $58.6 \pm 6.0 \mathrm{c}$ & $77.2 \pm 5.0 \mathrm{c}, \mathrm{d}, \mathrm{e}$ \\
\hline \multicolumn{10}{|c|}{ Factor ANOVA } \\
\hline \multicolumn{2}{|c|}{ Variables } & Sources & \multicolumn{2}{|c|}{ Enzyme and buffer combinations } & Time & \multicolumn{2}{|c|}{$\begin{array}{l}\text { Enzyme and buffer combinations } X \\
\text { Time }\end{array}$} & $R^{2}$ & LSD \\
\hline \multirow{4}{*}{\multicolumn{2}{|c|}{$\begin{array}{c}\text { Yield } \\
\left(\times 10^{6} \text { protoplasts } / \mathrm{gFW}\right)\end{array}$}} & Leaves & \multirow{2}{*}{\multicolumn{2}{|c|}{ * }} & NS & \multicolumn{2}{|c|}{$* *$} & 0.777 & 1.9 \\
\hline & & Flowers & & & NS & \multicolumn{2}{|c|}{ NS } & 0.603 & - \\
\hline & & Stems & \multicolumn{2}{|c|}{ NS } & $* *$ & \multicolumn{2}{|c|}{$* *$} & 0.978 & 0.3 \\
\hline & & Callus & \multicolumn{2}{|c|}{$* *$} & $* *$ & \multicolumn{2}{|c|}{$* *$} & 0.965 & 2.8 \\
\hline & & Leaves & \multirow{2}{*}{\multicolumn{2}{|c|}{$\begin{array}{l}* * \\
\text { NS }\end{array}$}} & $* *$ & \multicolumn{2}{|c|}{$* *$} & 0.983 & 8.7 \\
\hline \multicolumn{2}{|c|}{$\begin{array}{l}\text { Viability } \\
(\%)\end{array}$} & Flowers & & & $* *$ & \multicolumn{2}{|c|}{$* *$} & 0.967 & 4.3 \\
\hline & & Stems & \multicolumn{2}{|c|}{ * } & ** & \multirow{2}{*}{\multicolumn{2}{|c|}{$*$}} & 0.943 & 4.1 \\
\hline & & Callus & \multicolumn{2}{|c|}{$* *$} & $* *$ & & & 0.887 & 5.7 \\
\hline
\end{tabular}

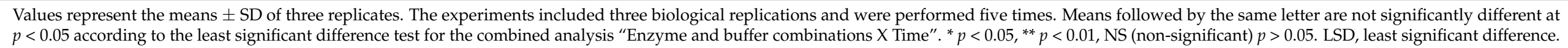




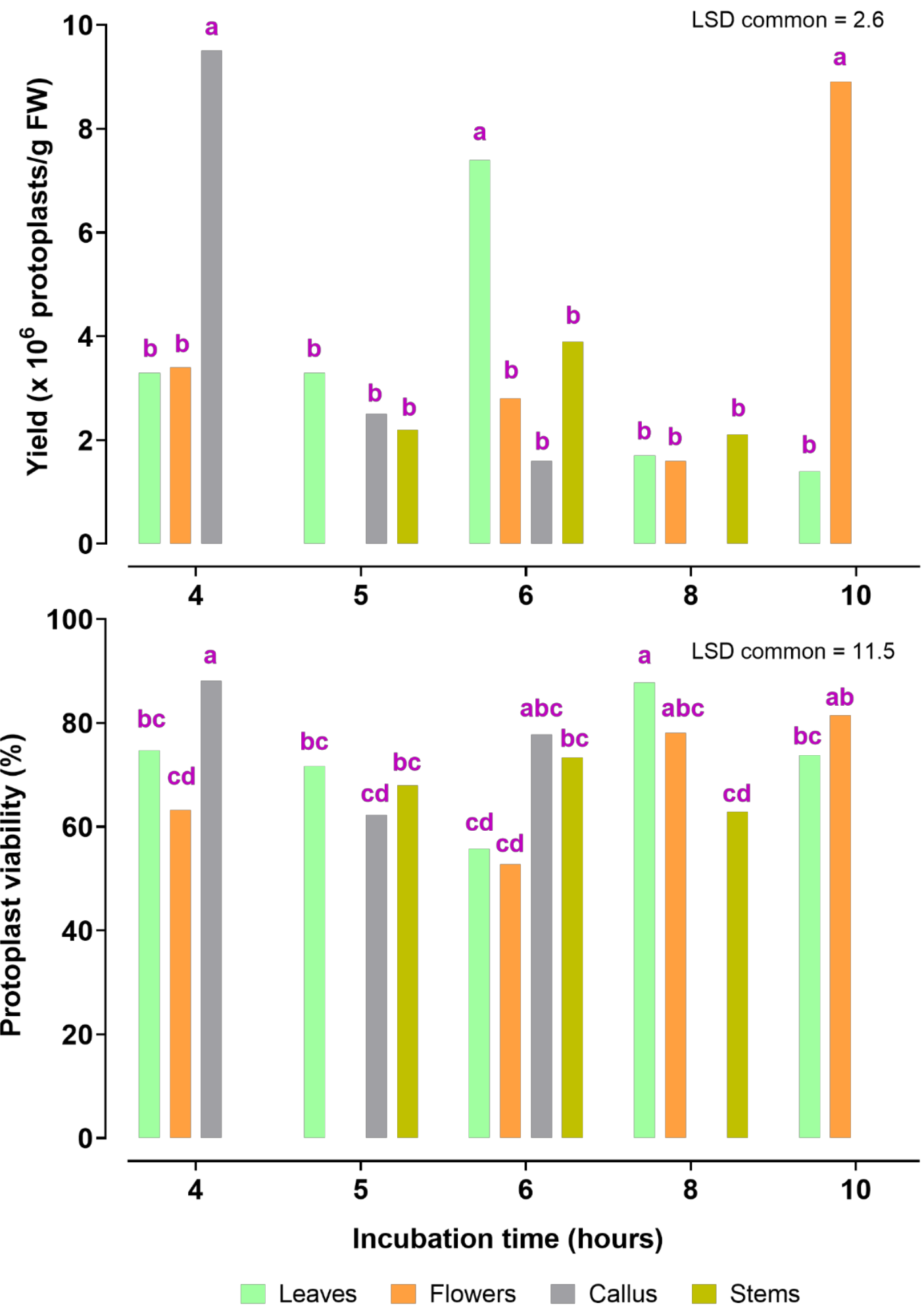

Figure 3. Effect of enzymolysis time on protoplast yield and viability of J. sambac L. protoplasts isolated from different sources (leaf, flower, stem, and callus tissues). The results were obtained in different hours of enzymolysis under constant temperature $26^{\circ} \mathrm{C}$. Values represent the means of three replicates. Means labeled by the same letter are not significantly different at $p<0.05$ according to the least significant difference test.

The enzyme volume had no significant effect on the protoplast number or their viability regardless of the explant origin for J. sambac (Figure 4). On the contrary, the 
enzyme solution volume significantly influenced the yield and viability of protoplasts from callus. The optimal volume of enzymes for J. sambac was $5 \mathrm{~mL}$, resulting in a yield of $13.2 \times 10^{6}$ protoplasts/gFW and viability of $91.6 \%$ (Figure 4 ).
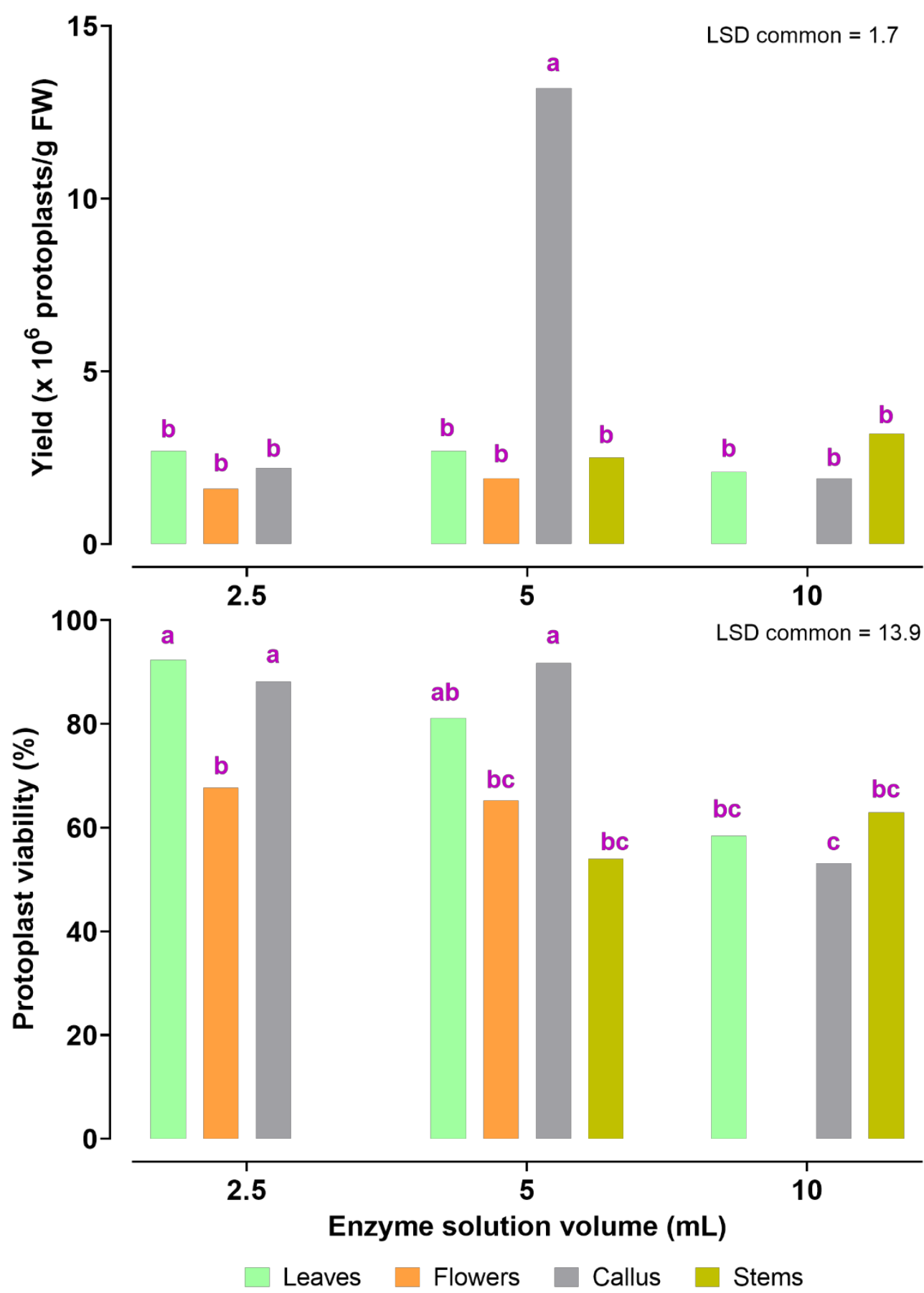

Figure 4. Effects of different volumes of enzyme solution $(\mathrm{mL})$ on yield and viability of protoplasts isolated from different sources of $J$. sambac L. The upper left figure from leaf, the upper right one from flower, and the bottom figures are the ones from stem and callus tissues, respectively. Values represent the means of three replicates. Means labeled by the same letter are not significantly different at $p<0.05$ according to the least significant difference test.

Next, to test the transformation of $J$. sambac protoplasts for transient expression, both isolated protoplasts and isolated plasmids were treated with 40\% PEG for $12 \mathrm{~h}$ to achieve transformation of protoplasts. A successful transformation with a plastid marker (atsip2) and jsSWEET5 tagged with GFP and mCherry was achieved. The JsSWEET5-GFP fusion 
protein clearly showed a plasma membrane (PM) localization in jasmine protoplasts. At the same time, there was a distinct spot-like distribution in the cytoplasm (Figure 5), while atsip2-mCherry was mainly localized to the endoplasmic reticulum (ER) in jasmine protoplasts (Figure 5). This protoplast-based transient expression system provides technical support for the rapid functional characterization of key genes in J. sambac.

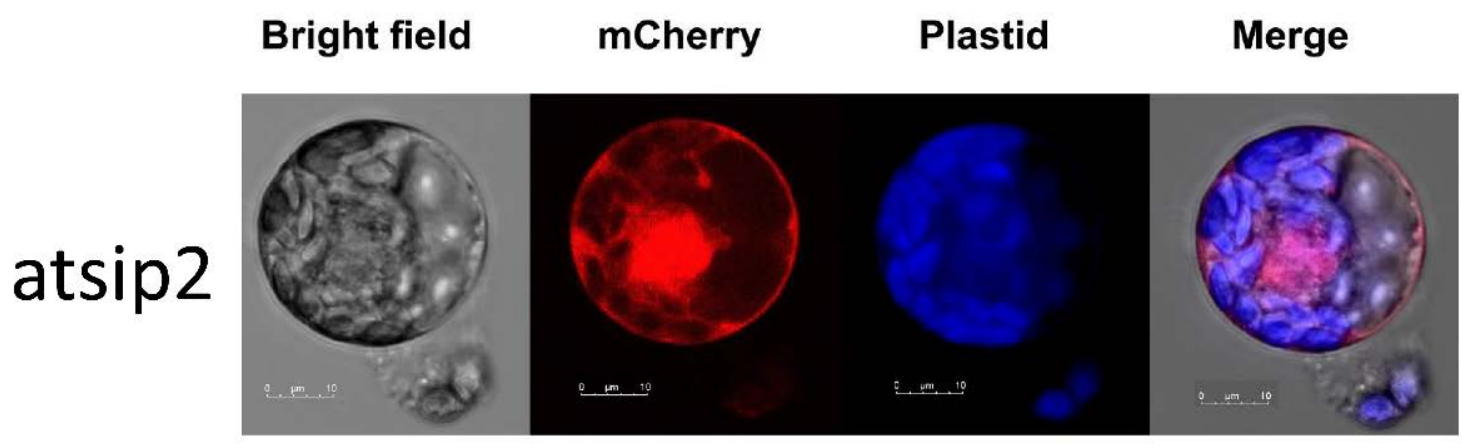

\section{Bright field}

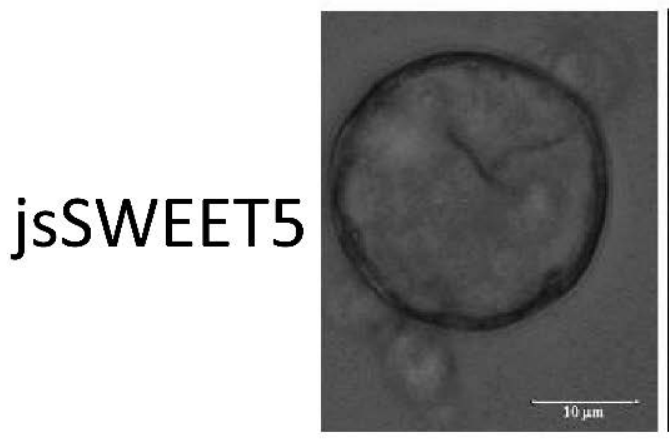

GFP

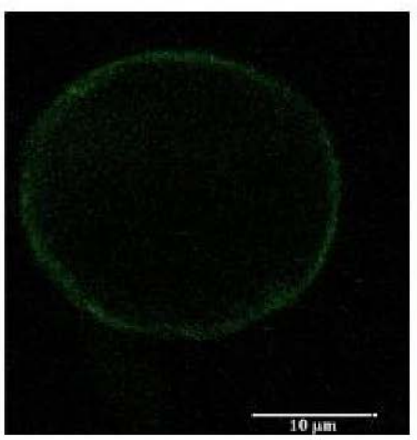

Merge

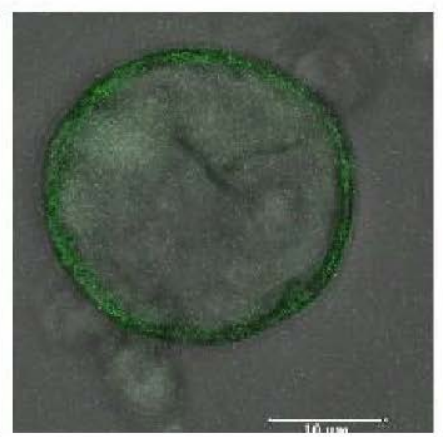

Figure 5. PEG-mediated protoplast transformation and expression in jasmine callus protoplasts. An mCherry-tagged Arabidopsis ER protein AtSIP2 and a GFP-tagged Jasminum plasma membrane protein JsSWEET5 were used as markers for successful expression. The bars represent $10 \mu \mathrm{m}$.

\subsection{Observation of the Cell Wall Regeneration and Optimization of PEG-Mediated Protoplast Fusion}

Cellulose accumulation is a good indication of cell wall regeneration, which can be visualized using Calcofluor staining. Using the method, we observed that $12 \mathrm{~h}$ after the cell-wall removal, new cellulose started to be synthesized again, and after $24 \mathrm{~h}$, the cell wall was completely formed all over the cell surface. After $36 \mathrm{~h}$, the completed cell wall could be observed (Figure 6a). The first $12 \mathrm{~h}$ were critical for cell wall formation because during this time, protoplasts were suitable for fusion and transformation events. Through the first and second day of culture, the protoplasts lose their spherical shape, which shows that the cell wall has been regenerated. Through the first day, no apparent changes were noticed in the cultured protoplasts form. Two days later, most protoplasts appeared larger and oval, indicating regeneration of a new cell wall. The protoplasts first cell division ensued following 3 days of culture. After five days, the second and third cell divisions took place (Figure 6b). Then, the cells underwent further division in quick succession. 


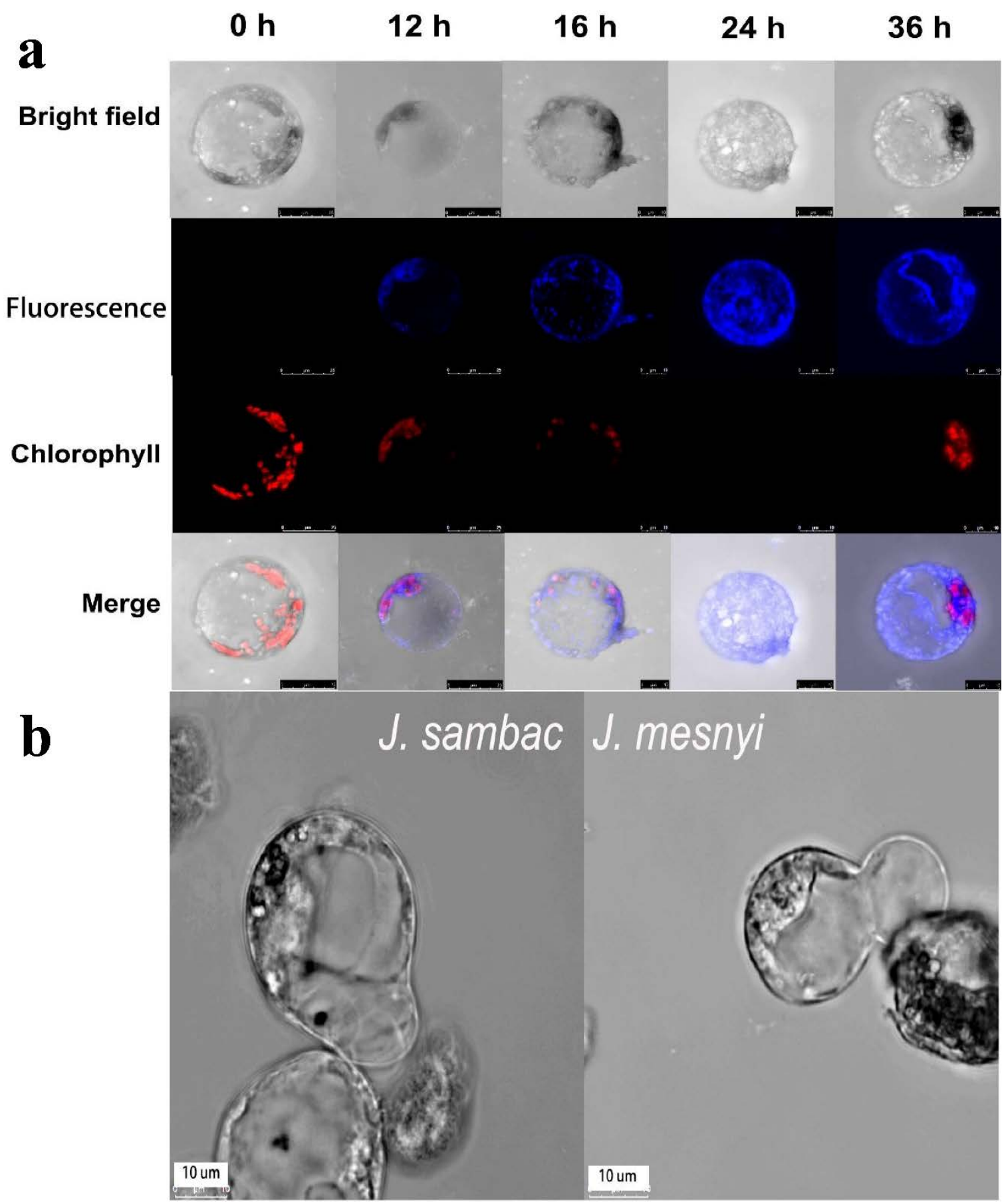

Figure 6. Regeneration of cellulosic cell walls of cultured protoplasts from callus of J. sambac. (a) Time course of cell wall regeneration in protoplasts, the protoplasts were incubated for $0,12,16,24$ and $36 \mathrm{~h}$ and stained with Calcofluor, bar $=25 \mu \mathrm{m}$. (b) Representative cell division images after 2.5 days of protoplast isolation.

ANOVA showed statistically significant differences at all treatments for the combination "Fusion solution $\times$ Fusion time $(\min )$ " (Table 4). As shown in Tables 5 and 6 , PEG-MW4000 and PEG-MW6000 influenced the protoplast fusion, which was clearly observed using fluorescence microscopy. The higher molecular weight PEG (6000) yielded higher fusions frequencies than the lower molecular weight PEG (4000) (Table 5). The protoplasts obtained by separating the callus of both Jasminum species could be contacted and integrated. Increasing the duration time of PEG treatment resulted in protoplast shrinkage. Decreasing the PEG treatment duration time $(15 \mathrm{~min})$ resulted in protoplasts separation. 
Successful fusions were achieved when the fusions were conducted with PEG-MW6000 $(40 \%)(w / v)$ supplemented with $0.1 \mathrm{M} \mathrm{CaCl}_{2}, 0.1 \mathrm{M}$ sorbitol and $1 \mathrm{M}$ Tris for 20 min (Table 4).

Table 4. ANOVA results for the effect of different fusion solution and fusion time on protoplast fusion frequency (\%) between J. sambac.L and J. mesnyi.

\begin{tabular}{|c|c|c|c|c|c|}
\hline & $\begin{array}{l}\text { Fusion } \\
\text { Solution }\end{array}$ & $\begin{array}{l}\text { Fusion Time } \\
\text { (min) }\end{array}$ & $\begin{array}{l}\text { Fusion Solution X } \\
\text { Fusion Time (min) }\end{array}$ & $R^{2}$ & LSD $^{+}$ \\
\hline Fusion rate (binary fusion) (\%) & $* *$ & * & $* *$ & 0.998 & 1.8 \\
\hline Viability (\%) & $* *$ & $* *$ & $* *$ & 0.999 & 5.7 \\
\hline
\end{tabular}

Table 5. Effect of different fusion solution and fusion time on protoplast fusion frequency $(\%)$ between J. sambac L. and J. mesnyi.

\begin{tabular}{|c|c|c|c|}
\hline Fusion Solution & Fusion Time (min) & Fusion Rate (Binary Fusion) (\%) & Viability (\%) \\
\hline \multirow{4}{*}{1} & 15 & $0 \pm 0 \mathrm{~d}$ & $0 \pm 0 \mathrm{e}$ \\
\hline & 20 & $0 \pm 0 \mathrm{~d}$ & $0 \pm 0 \mathrm{e}$ \\
\hline & 25 & $0 \pm 0 \mathrm{~d}$ & $0 \pm 0 \mathrm{e}$ \\
\hline & 15 & $1.34 \pm 0.05 \mathrm{c}, \mathrm{d}$ & $25.06 \pm 0.42 c$ \\
\hline \multirow[t]{3}{*}{2} & 20 & $2.04 \pm 0.06 c$ & $33.33 \pm 4.27 \mathrm{~b}$ \\
\hline & 25 & $1.54 \pm 0.05 \mathrm{c}, \mathrm{d}$ & $22.23 \pm 0.21 \mathrm{c}, \mathrm{d}$ \\
\hline & 15 & $0 \pm 0 \mathrm{~d}$ & $0 \pm 0 \mathrm{e}$ \\
\hline \multirow[t]{3}{*}{3} & 20 & $0 \pm 0 \mathrm{~d}$ & $0 \pm 0 \mathrm{e}$ \\
\hline & 25 & $0 \pm 0 \mathrm{~d}$ & $0 \pm 0 \mathrm{e}$ \\
\hline & 15 & $1.23 \pm 0.01 \mathrm{c}, \mathrm{d}$ & $18.23 \pm 0.35 \mathrm{~d}$ \\
\hline \multirow[t]{3}{*}{4} & 20 & $1.16 \pm 0.02 \mathrm{c}, \mathrm{d}$ & $22.27 \pm 0.42 \mathrm{c}, \mathrm{d}$ \\
\hline & 25 & $2.83 \pm 0.04 b, c$ & $48.81 \pm 0.21 \mathrm{a}$ \\
\hline & 15 & $2.67 \pm 0.21 \mathrm{~b}, \mathrm{c}$ & $36.07 \pm 0.66 \mathrm{a}, \mathrm{b}$ \\
\hline \multirow[t]{3}{*}{5} & 20 & $5.61 \pm 0.29 \mathrm{a}$ & $54.45 \pm 0.57 \mathrm{a}$ \\
\hline & 25 & $4.42 \pm 0.16 \mathrm{a}, \mathrm{b}$ & $39.09 \pm 0.36 \mathrm{a}$ \\
\hline & 15 & $0 \pm 0 \mathrm{~d}$ & $0 \pm 0 \mathrm{e}$ \\
\hline \multirow[t]{2}{*}{6} & 20 & $0 \pm 0 \mathrm{~d}$ & $0 \pm 0 \mathrm{e}$ \\
\hline & 25 & $0 \pm 0 \mathrm{~d}$ & $0 \pm 0 \mathrm{e}$ \\
\hline
\end{tabular}

Data are means of three independent treatments. Means followed by the same letter are not significantly different at $p<0.05$ according to the least significant difference test for the combined analysis "Fusion solution X Fusion time (min)".

Table 6. Effect of different molecular weight of PEG on protoplast fusion between J. sambac L. and J. mesnyi.

\begin{tabular}{ccc}
\hline PEG MW $(\%(w / v))$ & Fusion Rate (\%) & Viability (\%) \\
\hline 4000 & $2.08 \pm 0.05 \mathrm{~b}$ & $25.72 \pm 0.84 \mathrm{~b}$ \\
6000 & $5.64 \pm 0.19 \mathrm{a}$ & $47.76 \pm 0.92 \mathrm{a}$ \\
\hline
\end{tabular}

Data are means of three independent treatments. Differences between means were assessed using $t$-test; means with the same letter are not significantly different at $95 \%$ interval of confidence $(p<0.05)$.

Optimization of protoplast fusion parameters is a prerequisite to establishing a somatic fusion technology for jasmine breeding. Regarding frequency of binary fusion, treatment with $40 \%$ PEG $6000 \mathrm{MW}$ for $20 \mathrm{~min}$ proved to be the best combination with a fusion rate of $5 \%$.

\subsection{Protoplasts Culture and Microcallus Formation}

Protoplasts that were successfully isolated from callus tissue had a spherical shape (Figure 7a). Protoplasts from both Jasminum species have completed the development of the cell wall after the seventh day in agarose and liquid media, and cell division began (Figure 7). The protoplasts of J. sambac were cultured on both protoplast culture medium, PCM1 (MS culture medium containing $2 \mathrm{mg} / \mathrm{L}$ 6-BA + $0.2 \mathrm{mg} / \mathrm{L}$ NAA) and PCM2 (MS culture medium containing $0.1 \mathrm{mg} / \mathrm{L} \mathrm{BAP}+2 \mathrm{mg} / \mathrm{L}$ NAA). Protoplasts of $J$. mesnyi were cultured on both PCM3 (MS culture medium containing $1 \mathrm{mg} / \mathrm{L} 6-\mathrm{BA}+2 \mathrm{mg} / \mathrm{L}$ NAA) and PCM4 (MS culture medium containing $0.5 \mathrm{mg} / \mathrm{L} \mathrm{2,4-D).} \mathrm{The} \mathrm{results} \mathrm{indicated} \mathrm{that}$ protoplasts culture on PCM1 medium produced higher plating efficiency over on PCM2, and protoplasts culturing on PCM3 medium led to higher plating efficiency over on PCM4. 
Despite the weekly addition of fresh medium, protoplasts culture turned brown. To prevent culture contaminations, Clorox (5.5\% sodium hypochlorite) was added into WPM and MS media at $4 \mathrm{~mL} / 1 \mathrm{~L}$ (personal communication with Prof. Aboul-Nasr, M.H.). After 3-5 weeks, either PCM1 or PCM3 protoplast cells of J. sambac and J. mesnyi continued to divide, and multicellular aggregates were formed (Figure 7). After 8 weeks of culture, micro calli were formed, and the calli lines obtained were placed on an $0.8 \%$ agar-solidified WPM, but protoplast-derived calli were very few and grew weakly.

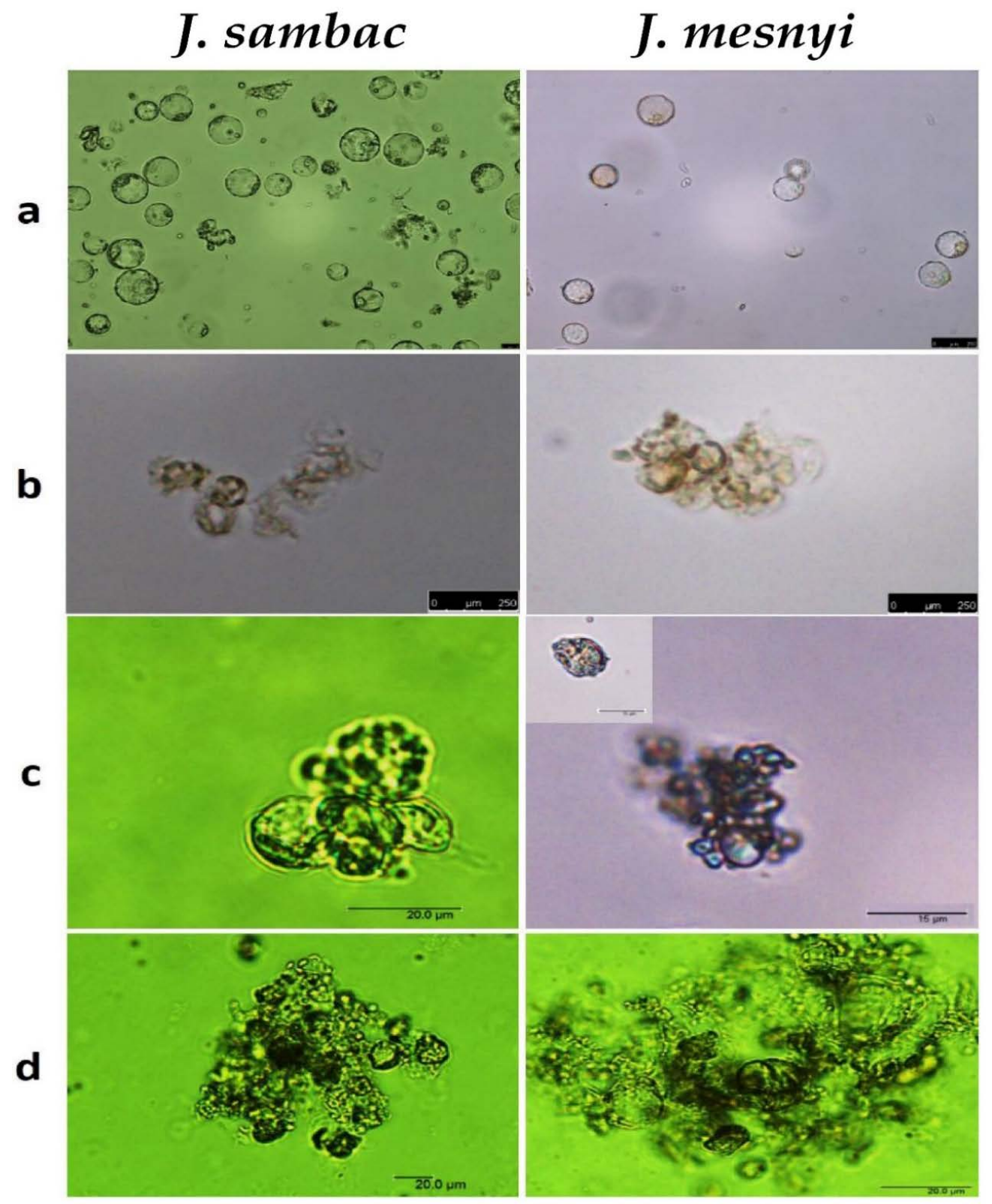

Figure 7. General overview of protoplast culture for J. sambac and J. mesnyi. (a) Isolated protoplast from callus tissues, bar $100 \mu \mathrm{m}$, (b) first division of protoplast after two days of culture, bar $200 \mu \mathrm{m}$, (c) second division of protoplast after seven days of culture, bar $50 \mu \mathrm{m}$, (d) protoplast-derived microcolony formation after three weeks of culture, bar $100 \mu \mathrm{m}$.

\section{Discussion}

Shoot culture strategies have been used for most of the woody crops as a first method for microculture. For this strategy, stimulation of axillary buds is the primary purpose. If vigorous shoot culture is accomplished, the shoot culture itself is a reliable stock for supplying tissues for biotechnological manipulations or micro-shoots for cloning [30]. This 
dependency on shoot cultures as a general supplier of tissue has the distinctive benefit of eliminating the difficulties related to seasonal growth, dormancy and extended in vitro establishment times that must be faced any time when new explants of woody species are re-isolated for any use.

Here, our results indicated that WPM medium supplemented with $2 \mathrm{mg}$ BAP/L and $0.2 \mathrm{mg} \mathrm{NAA} / \mathrm{L}$ is an efficient medium for callus induction for the two Jasminum species studied. The young stems of $J$. sambac placed in MS medium supplemented with 2,4-D (0.5 g/L) developed calli, as it was observed by [31]. Furthermore, MS medium supplemented with $4 \mathrm{mg} / \mathrm{L} \mathrm{BA}+0.1 \mathrm{mg} / \mathrm{L} 2,4-\mathrm{D}$ and $6 \mathrm{mg} / 16-\mathrm{BA}+0.1 \mathrm{mg} / \mathrm{L} \mathrm{2,4-D}$ presented a high percentage of callus induction, whereas a high number of buds (10.1) was recorded in the combination of $4 \mathrm{mg} / \mathrm{L} 6-\mathrm{BA}+2 \mathrm{mg} / \mathrm{L}$ Kin from the inter-nodal explants of J. azoricum [32]. Hence, the genetic mechanism underlying the variation in callus formation of different species and even in different genotypes of the same species when the same kind of explants were used is not known [33]. During callus induction, it was found that most of the cells formed by dedifferentiation, which occurred around the phloem cells and continued to spread to the surrounding area, resulting in continuous expansion and formation of callus. In general, although the calli induced from the jasmine stem segment had a particular globular shape, it is suspected that they might be embryogenic callus clusters and can also form bud-like protrusions. However, it seems difficult to completely differentiate into organs such as leaves and shoots in Jasminum species, and thus, successful callus culture and plantlet regeneration from the genus Jasminum are seldom reported in the literature.

To the best of our knowledge, no reports on protoplast culture and regeneration of J. sambac and J. mesnyi have been published, and thus this study is the first report on protoplast culture, and fusion of J. sambac and J. mesnyi. Although we failed in a microcolony formation and regeneration of plantlets under the conditions tested, calli culture were obtained and provided a base for further optimization. Thus, our results provide a realistic basis for future work on the development of a protoplast to a plant regeneration system. Furthermore, even at the stage of callus, the two species can be used for biotechnological applications, especially as the transformation of protoplasts is feasible as we show here. Future research should focus on plant regeneration from protoplast-derived callus, and further efforts should be made to accomplish the shoot regeneration system. Developing an efficient regenerative protoplast strategy is based on diverse factors associated with culture conditions in many sequential steps. To optimize in vitro culture, testing of diverse parameters is required, including cultivation settings, PGR supplementation, and media composition [34]. In this study, for protoplast culture, MS liquid medium was used, and auxins and cytokinins were the major growth regulators for sustained protoplast growth.

The optimal time to isolate protoplast from callus was $4 \mathrm{~h}$. The results of the obtained protoplasts from callus tissues matched with that obtained by [34], who stated that the optimal time to isolate the protoplasts in Dendrobium was $4 \mathrm{~h}$. Following $6 \mathrm{~h}$ of incubation, a reduction in both yield and viability of protoplasts was observed because of the prolonged incubation period, resulting in the rupture of protoplasts. The ability to isolate a high number of healthy protoplasts allowed for a successful protoplast culturing and efficiently developed a protoplast-to-plant system [35]. Nevertheless, such establishment is affected by several factors, among others: genotype, physiological status and growing environments of the protoplast source tissue, protoplast isolation and medium composition [36]. Young shoots or leaves and callus 2-3 months old generally yielded more protoplasts. When the callus tissue was incubated in a protoplast isolation solution containing $2 \%$ of cellulose and $0.1 \%$ pectinase, it produced the highest number of protoplasts $\left(1.37 \times 10^{5}\right.$ protoplasts $\mathrm{g}-1 \mathrm{FW})$ [37].

The difficulties associated with the culture and regeneration from protoplasts have been attributed to the genomic changes associated with differentiation [38]. The reduction of regeneration ability and even its loss is a general phenomenon observed among undifferentiated cell cultures [39]. The inability of protoplast-derived calli to regenerate shoots 
could be due to the accumulation of changes in the genetic make-up of the individual cultivars during the callus stage.

The highest fusion was accomplished when J. sambac and J. mesnyi protoplasts were placed in 40\% PEG (6000 molecular weight) for $20 \mathrm{~min}$. These findings are also supported by [24], who reported that the highest binary fusion rate was accomplished with fusion solution 3 comprising 30\% (w/v) PEG-MW6000 supplemented with $4 \%(w / v)$ sucrose and $10 \mathrm{mM} \mathrm{CaCl} 2 \cdot 2 \mathrm{H}_{2} \mathrm{O}$. It is obvious that optimum protoplast fusion is affected by different factors, including the molecular weight of PEG, percentage of PEG, duration of PEG treatment, concentration, and the duration of calcium chloride treatment. PEG with a molecular weight of 400 to 6000 showed activity in fusion over PEG 200 and 20,000 [40]. The sustained PEG application of over $30 \mathrm{~min}$ resulted in severe protoplast destruction [41]. The utilization of high concentration or high molecular weight PEG is shown to result in tighter protoplast adhesion but with limited recovery of viable fused cells. It was observed here that a $50 \%$ fusion solution promoted fusion, but it reduced viable fusion products. Furthermore, it is also significant to recognize that the appropriate PEG molecular weight and exposure time can affect the viable protoplast yield [24]. Jin Wanmei and others [42] stated that the use of PEG for prolonged duration reduced the viability of protoplasts and regeneration of the cell wall, cell division and production of microcolonies. Such findings followed the previously published work of utilizing 30\% (w/v) PEG incubated to $30 \mathrm{~min}$ to induce fused protoplast [40].

The use of protoplasts for transient transformation overcomes the regeneration problem to a certain extent; however, an efficient regeneration system from protoplasts to plants is highly necessary. This work developed an efficient protocol for PEG-mediated transformation. Protoplast transient expression systems have been developed to be used in plants, including Arabidopsis [43] for studying gene function, protein subcellular localization, and protein-protein interactions. They depend on a high yield of isolated protoplasts with high viability from healthy plants [44].

\section{Conclusions}

Jasmine stem explants are relatively easy to induce callus, and WPM medium supplemented with $30 \mathrm{~g} / \mathrm{L}$ sucrose, $8 \mathrm{~g} / \mathrm{L}$ agar, $2 \mathrm{mg} / \mathrm{L}$ 6-BA and $0.2 \mathrm{mg} / \mathrm{L}$ NAA was the best medium for callus induction. The combination of cytokinin 6-BA and auxin NAA is more effective than other plant growth regulators when the callus is induced from the stem and leaf segments of jasmine. The study here provides an efficient protocol to isolate protoplasts from different tissues of J. samab and J. mesnyi. The isolation settings affect the efficient number of protoplasts derived from different tissues of J. samab and J. mesnyi. Callus tissues of J. samab and J. mesnyi were proved to be the most appropriate source of tissue for protoplast isolation. Finally, fusion of protoplasts was achieved using $40 \%$ PEG (6000 molecular weight) for $20 \mathrm{~min}$.

Supplementary Materials: The following are available online at https:/ / www.mdpi.com/article/10.3 390/agriculture11080699/s1, Table S1: Callus induction rate of stem segments and leaves under different induction media of J. sambac and J. mesnyi. Figure S1: Effect of 6-BA and NAA on callus induction.

Author Contributions: Conceptualization, M.A.A.A. and B.W.; methodology, M.A.A.A., W.W., J.I. and B.W.; validation, A.F.Y., M.L., J.I. and B.W.; formal analysis, M.A.A.A., P.M., E.D.P., W.W., M.M. and M.L.; investigation, M.A.A.A., W.W., J.I., Y.Y., M.M. and A.F.Y.; data curation, M.A.A.A., J.I., M.L., H.Z., Y.Y. and B.W.; writing-original draft preparation, M.A.A.A.; writing-review and editing, P.M and B.W.; supervision, B.W. All authors have read and agreed to the published version of the manuscript.

Funding: This work received no external funding.

Institutional Review Board Statement: Not applicable.

Informed Consent Statement: Not applicable. 
Data Availability Statement: The data presented in this study are available within the paper and within its supplementary materials published online. Further information may be obtained from the corresponding author, $\mathrm{B}$. $\mathrm{Wu}$.

Acknowledgments: The authors are grateful to Aboul-Nasr, M.H and Shimaa Hassan Mosallam, West Hills Community College, Coalinga (WHCCD), USA for their assistance to proofread our manuscript.

Conflicts of Interest: The authors declare no conflict of interest.

\section{References}

1. Chaitanya, H.S.; Nataraja, S.K.M. Review on Propagation Techniques of Jasmine (Jasminum sambac (L.)). J. Pharmacogn. Phytochem. 2018, 7, 593-596.

2. Lu, Y.; Liu, Z.; Lyu, M.; Yuan, Y.; Wu, B. Characterization of JsWOX1 and JsWOX4 during callus and root induction in the shrub species Jasminum sambac. Plants 2019, 8, 79. [CrossRef] [PubMed]

3. Hussain, A.; Qarshi, I.A.; Nazir, H.; Ullah, I. Plant Tissue Culture: Current Status and Opportunities. In Recent Advances in Plant In Vitro Culture; Leva, A., Rinaldi, L., Eds.; IntechOpen: London, UK, 2012; pp. 1-28.

4. Brown, D.C.W.; Thorpe, T.A. Crop improvement through tissue culture. World J. Microbiol. Biotechnol. 1995, 11, 409-415. [CrossRef] [PubMed]

5. Mccown, B. Special symposium: In vitro recalcitrance. Recalcitrance of woody and herbaceous perennial plants: Dealing with genetic predeterminism. Vitr. Cell. Dev. Biol. 2000, 36, 149-154. [CrossRef]

6. Ruisheng, G.; Xiangning, J.; Zhongchen, G. Research progress on the mechanism of organogenesis in vitro culture of plants. Chin. J. Bot. 1999, 16, 238-244.

7. Naibo, Y. Tissue culture and organogenesis of several woody Plants. Chin. J. Plant Physiol. 1982, 4, $25-29$.

8. Umate, P.; Rao, K.V.; Kiranmayee, K.; Sree, T.J.; Sadanandam, A. Plant regeneration of mulberry (Morus indica) from mesophyllderived protoplasts. Plant Cell Tissue Organ Cult. 2005, 82, 289-293. [CrossRef]

9. Duquenne, B.; Eeckhaut, T.; Werbrouck, S.; Van Huylenbroeck, J. Effect of enzyme concentrations on protoplast isolation and protoplast culture of Spathiphyllum and Anthurium. Plant Cell Tissue Organ Cult. 2007, 91, 165-173. [CrossRef]

10. Prabavathy, V.R.; Mathivanan, N.; Sagadevan, E.; Murugesan, K.; Lalithakumari, D. Intra-strain protoplast fusion enhances carboxymethyl cellulase activity in Trichoderma reesei. Enzym. Microb. Technol. 2006, 38, 719-723. [CrossRef]

11. Nassour, M.; Dorion, N. Plant regeneration from protoplasts of micropropagated Pelargonium x hortorum "Alain": Effect of some environmental and medium factors on protoplast system efficiency. Plant Sci. 2002, 163, 169-176. [CrossRef]

12. Makonkawkeyoon, S.; Smitamana, P.; Hirunpetcharat, C.; Maneekarn, N. Production of mouse immunoglobulin G by a hybrid plant derived from tobacco-mouse cell fusions. Experentia 1995, 51, 19-25.

13. Hassanein, A.; Hamama, L.; Loridon, K.; Dorion, N. Direct gene transfer study and transgenic plant regeneration after electroporation into mesophyll protoplasts of Pelargonium x hortorum, "Panaché Sud". Plant Cell Rep. 2009, 28, 1521-1530. [CrossRef]

14. Shen, Y.; Meng, D.; McGrouther, K.; Zhang, J.; Cheng, L. Efficient isolation of Magnolia protoplasts and the application to subcellular localization of MdeHSF1. Plant Methods 2017, 13, 1-10. [CrossRef] [PubMed]

15. Zhang, Y.; Su, J.; Duan, S.; Ao, Y.; Dai, J.; Liu, J.; Wang, P.; Li, Y.; Liu, B.; Feng, D.; et al. A highly efficient rice green tissue protoplast system for transient gene expression and studying light/chloroplast-related processes. Plant Methods 2011, 7, 1-14. [CrossRef]

16. Murashige, T.; Skoog, F. A revised medium for rapid growth and bio assays with tobacco tissue cultures. Physiol. Plant. 1962, 15, 473-497. [CrossRef]

17. Loyd, G.; McGown, B. Commercially-feasible micropropagation of mountain laurel, Kalmia latifolia, by use of shoot-tip culture. Proc. Int. Plant Propagators Soc. 1980, 30, 421-427.

18. Frey, D.D.; Wang, H. Adaptive one-factor-at-a-time experimentation and expected value of improvement. Technometrics 2006, 48, 418-431. [CrossRef]

19. Ling, A.P.K.; Phua, G.A.T.; Tee, C.S.; Hussein, S. Optimization of protoplast isolation protocols from callus of Eurycoma longifolia. J. Med. Plants Res. 2010, 4, 1778-1785.

20. Sangra, A.; Shahin, L.; Dhir, S.K. Optimization of isolation and culture of protoplasts in alfalfa (Medicago sativa) cultivar Regen-SY. Am. J. Plant Sci. 2019, 10, 1206-1219. [CrossRef]

21. Yoo, S.D.; Cho, Y.H.; Sheen, J. Arabidopsis mesophyll protoplasts: A versatile cell system for transient gene expression analysis. Nat. Protoc. 2007, 2, 1565-1572. [CrossRef] [PubMed]

22. Widholm, J.M. The use of fluorescein diacetate and phenosafranine for determining viability of cultured plant cells. Stain Technol. 1972, 47, 189-194. [CrossRef] [PubMed]

23. Larkin, P.J. Purification and viability determinations of plant protoplasts. Planta 1976, 128, 213-216. [CrossRef]

24. Durieu, P.; Ochatt, S.J. Efficient intergeneric fusion of pea (Pisum sativum L.) and grass pea (Lathyrus sativus L.) protoplasts. J. Exp. Bot. 2000, 51, 1237-1242.

25. Menczel, L.; Wolfe, K. High frequency of fusion induced in freely suspended protoplast mixtures by polyethylene glycol and dimethylsulfoxide at high pH. Plant Cell Rep. 1984, 3, 196-198. [CrossRef] 
26. Assani, A.; Chabane, D.; Haïcour, R.; Bakry, F.; Wenzel, G.; Foroughi-Wehr, B. Protoplast fusion in banana (Musa spp.): Comparison of chemical (PEG: Polyethylene glycol) and electrical procedure. Plant Cell Tissue Organ Cult. 2005, 83, 145-151. [CrossRef]

27. Hayat, S.; Christias, C. Isolation and fusion of protoplasts from the phytopathogenic fungus Sclerotium rolfsii (Sacc.). Braz. J. Microbiol. 2010, 41, 253-263. [CrossRef]

28. Geerts, P.; Druart, P.; Ochatt, S.; Baudoin, J.P. Protoplast fusion technology for somatic hybridisation in Phaseolus. Biotechnol. Agron. Soc. Environ. 2008, 12, 371-377.

29. Peng, Z.; Tong, H.R.; Liang, G.L.; Shi, Y.Q.; Yuan, L.Y. Protoplast isolation and fusion induced by PEG with leaves and roots of tea plant (Camellia sinensis L. O. Kuntze). Acta Agron. Sin. 2018, 44, 463-470. [CrossRef]

30. McCown, B.H. From gene manipulation to forest establishment: Shoot cultures of woody plants can be a central tool. Tappi 1985, 68, 116-119.

31. U-Kong, W.; Wongsawad, P.; Buddharak, P. Shoot bud and young leaf induction of Jasminum spp. in in vitro culture. Int. J. Appl. Agric. Res. 2012, 7, 17-26.

32. Salim, S.A.A. Effect of plant growth regulators BA, 2,4-D, IBA and Kin on in vitro propagation of white jasmine (Jasminum azoricum L.). J. Univ. Babylon 2016, 24, 795-802.

33. Kareem, A.; Radhakrishnan, D.; Sondhi, Y.; Aiyaz, M.; Roy, M.V.; Sugimoto, K.; Prasad, K. De novo assembly of plant body plan: A step ahead of Deadpool. Regeneration 2016, 3, 182-197. [CrossRef]

34. Aqeel, R.; Zehra, M.; Kazmi, S.K.; Khan, S.; Kayani, H.A.; Mirbahar, A.A. A study on the isolation of protoplasts from mesophyll cells of Dendrobium Queen Pink. Pak. J. Bot. 2016, 48, 693-697.

35. Rahmani, M.S.; Pijut, P.M.; Shabanian, N. Protoplast isolation and genetically true-to-type plant regeneration from leaf- and callus-derived protoplasts of Albizia julibrissin. Plant Cell Tissue Organ Cult. 2016, 127, 475-488. [CrossRef]

36. Eeckhaut, T.; Lakshmanan, P.S.; Deryckere, D.; Van Bockstaele, E.; Van Huylenbroeck, J. Progress in plant protoplast research. Planta 2013, 238, 991-1003. [CrossRef]

37. Chamani, E.; Tahami, S.K. Efficient protocol for protoplast isolation and plant regeneration of Fritillaria imperialis L. J. Agric. Sci. Technol. 2016, 18, 467-482.

38. Mohan Jain, S. Tissue culture-derived variation in crop improvement. Euphytica 2001, 118, 153-166. [CrossRef]

39. Hesemann, C.U.; Schröder, G. Loss of nuclear DNA in leaves of rye. Theor. Appl. Genet. 1982, 62, 325-328. [CrossRef] [PubMed]

40. Melchers, G. Microbial techniques in somatic hybridisation by fusion of protoplasts. In International Cell Biology; Brinkley, B.R., Porter, K.R., Eds.; Rockefeller University Press: Boston, MA, USA, 1977; pp. 207-215.

41. Guan, Q.; Guo, Y.; Wei, Y.; Meng, F.; Zhang, Z. Regeneration of somatic hybrids of ginger via chemical protoplast fusion. Plant Cell Tissue Organ Cult. 2010, 102, 279-284. [CrossRef]

42. Wanmei, J.; Zhenhui, G.; Guirong, L. Plant genetic transformation methods and identification of transgenic plants. Shaanxi Agric. Sci. 2000, 1, 24-29.

43. Wu, F.H.; Shen, S.C.; Lee, L.Y.; Lee, S.H.; Chan, M.T.; Lin, C.S. Tape-arabidopsis sandwich-A simpler arabidopsis protoplast isolation method. Plant Methods 2009, 5, 1-10. [CrossRef] [PubMed]

44. Endress, R. Plant cells as producers of secondary compounds. In Plant Cell Biotechnology; Springer: Berlin/Heidelberg, Germany, 1994; pp. 121-255. 